\title{
Descriptions of the larvae of two stonefly species of the genus Capnia Pictet (Plecoptera: Capniidae)
}

\section{Описание мичинки двух видов веснянок рода Capnia Pictet (Plecoptera: Capniidae)}

\author{
V.A. Teslenko*, D.M. Palatov** \\ B.A. Тесленко*, А.М. Палатов ${ }^{* *}$
}

\begin{abstract}
* Federal Scientific Center of the East Asia Terrestrial Biodiversity, FEB, RAS, Prosp. 100-letiya Vladivostoka 159, Vladivostok 690022 Russia. E-mail: teslenko@biosoil.ru.

* Федеральный научный центр биоразнообразия наземной биоты Восточной Азии ДВО РАН, пр. 100-летия Владивостока 159, Владивосток 690022 Россия.

** A.N. Severtsov Institute of Ecology and Evolution, RAS, Leninskii Prosp. 33, Moscow 119071 Russia. E-mail: triops@yandex.ru.

** Институт проблем экологии и эволюции имени А.Н. Северцова РАН, Ленинский пр. 33, Москва 119071 Россия.
\end{abstract} Shan.

Key words: stoneflies, larvae, Capnia arensi, Capnia (Capnia) longicauda, Greater Caucasus, Eastern Tien-

Ключевые слова: веснянки, личинки, Capnia arensi, Capnia (Capnia) longicauda, Большой Кавказ, Восточный Тянь-Шань.

\begin{abstract}
Larvae of two stonefly species, Capnia arensi Zhiltzova, 1964 and Capnia (Capnia) longicauda Zhiltzova, 1969, collected from the Greater Caucasus and Eastern TienShan mountains are described and illustrated for the first time. Details of chaetotaxy of the mouthparts, head, pronotum, legs, abdominal and cercal segments are revealed by scanning electron and light microscopy.
\end{abstract}

Резюме. Впервые приведены описания личинки веснянок двух видов Capnia arensi Zhiltzova, 1964 и Capnia (Capnia) longicauda Zhiltzova, 1969 с Большого Кавказа и Восточного Тянь-Шаня. Детальные характеристики, включая хетотаксию ротовых частей, головы, ног и церкальных сегментов, выявлены с использованием электронной и световой микроскопии.

\section{Introduction}

Capnia Pictet, 1841 is the most species rich genus of the winter stonefly family Capniidae, currently includes more than one hundred species [DeWalt et al., 2021]. Murányi et al. [2014] provided a comprehensive revision of the Nearctic and West Palaearctic genera of the family and revealed Capnia as clearly polyphyletic genus, only a few species fit the concept of Capnia sensu stricto [Murányi et al., 2014]. Capnia adults are well-recognized by genital structures; the larvae remain little known due to lack of suitable distinguishing morphological characteristics. Generic separation of Capnia larvae is still the most problematic in immature Plecoptera [Stewart et al., 2011]. Significant contribution in diagnostic has been made recently for Nearctic species by Stewart and Stark [2002] and Stewart et al. [2011]. Studies of Capnia larvae were focused on pigment pattern; measurements of body length, head capsule width, and inside forewing pad length; counts of antennal and cercal segments; mouthparts; setal patterns; and shape of the last male abdominal segment. These same characters are considered for the following descriptions of the larvae of the Eurasian and Central Asian Capnia species.

Larvae were associated with adults by common occurrence. Adults and larvae of Capnia arensi Zhiltzova, 1964 and Capnia (Capnia) longicauda Zhiltzova, 1969 were collected by D. Palatov from the Greater Caucasus (North Ossetia, Russia) and Eastern TienShan (the Xinjiang Uygur Autonomous Region, China), respectively. Unknown larvae of these two species are described and illustrated in detail, including scanning electron and light microscopy. Additionally several measurements of setation found on pronotum, legs, abdominal, and cercal segments have been determined, which may be informative and useful diagnostic characters for separating of Capnia species.

\section{Material and methods}

The association of the mature larvae with adults was established from preemergent male larvae, collected together with adults. Adults and larvae of $C$. arensi were handpicked from the stones, snow, and ice at night with flashlight.

Illustrations were produced using digital cameras (Nikon Coolpix 995 and Toup View 3.7) and with the stereomicroscope Olympus SZX1 6 and digital camera Olympus DP74, and stacked using Helicon Focus software. The final illustrations were post processed for 
contrast and brightness using Adobe ${ }^{\circledR}$ Photoshop ${ }^{\circledR}$ software. Photographs were taken in the Federal Scientific Center of the East Asia Terrestrial Biodiversity, Far Eastern Branch, Russian Academy of Sciences, Vladivostok. For scanning electron microscopy, the larvae were gradually transferred to acetone, critical point dried, fixed on specimen stubs with double-sided and coated with gold by sputtering using Polaron PS 100 . The SEM images were made in the Paleontological Museum of the Paleontological Institute of the Russian Academy of Sciences, Moscow, by means of Vega3 Tescan microscope.

Terminology follows Nelson, Baumann [1989], Stewart, Stark [2002], and Murányi et al. [2014].

\section{Descriptions}

\author{
Capnia arensi Zhiltzova, 1964 \\ Figs $1-20$
}

Zhiltzova, 1964: 357, figs. 20-24, Illies, 1966: 131; Zwick, 1973: 391; Zhiltzova, 2003: 366, figs 616-619; Kazanci, 1982: 5; Teslenko, Zhiltzova, 2009: 198, figs 114-117; Vinçon, Sivec., 2011: 122; Murányi et al., 2014: 17, figs 15-16; Darilmaz et al., 2016: 5 .

Material. Russia: the Greater Caucasus, Republic of North Ossetia-Alania, Alagirskii Distr., Fiagdon River, Terek River Basin, above Harisdzhin vill., 4248'27.07" N, $44^{\circ} 14^{\prime} 27.86^{\prime \prime} \mathrm{E}$, altitude $1425 \mathrm{~m}$ a.s.l., 31.XII.2020, coll. D. Palatov, 2407 $0^{7}$, 3우, 7 larvae.

Description. Mature larvae. Body length: male larvae 6.7-7.8 mm, female larvae 7.7-9.4 mm. Light brown to brown: clear pattern in females, faint in males (Figs 1,2). Head brown, small diffuse pale spot in front of the anterior ocellus, epicranial suture is thin and pale, two pairs of dark brown tentorial

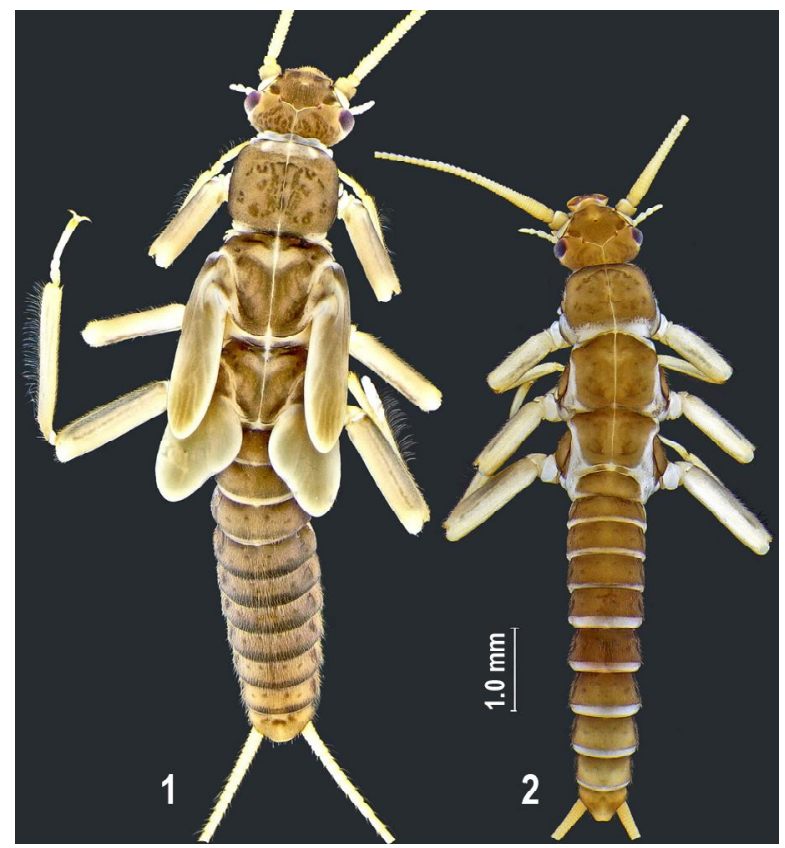

Figs 1-2. Capnia arensi Zhiltzova, larvae, female and male, habitus.

Рис. 1-2. Capnia arensi Zhiltzova, мичинка самки и самџа, общий виА. callosities on the clypeus and above lateral ocelli, paired small pale patches bordering epicranial suture near lateral edges of head; M-line is hard to observe; on occiput a brown occipital rugosities created a paired triangular pattern directed upward (Figs 1, 2). Antennae pale, with $>32$ segments. Mouthparts typical to euholognathan: small mentum, glossa in length subequal to paraglossa, both are triangular and rounded apically; labial palp short (Fig. 4). Trapezoidal labrum narrowed posteriorly, anterior corners rounded (Fig. 5). Galea fringed with a few bristles, hairs, and papilla apically; outer margin glabrous; lacinia triangular and palmate with longitudinally striate palm surface and four relatively broad apical teeth (Fig. 6). Dorsal comb of 20-25 strong bristles, and ventral comb of 7-12 bristles shorter and thinner than dorsal comb (Fig. 6). Right mandible (Fig. 8) basally wide with a rounded outer margin and six pointed apical teeth: three teeth larger than the rest, the first and third teeth serrated basally. Below the first apical teeth, a dense thin band of hairs form an arcuate curved inner row directed toward the molar pad; the molar pad is raised and covered with dense, short, stiff bristles. Left mandible also has six pointed apical teeth: third apical tooth is slightly serrated at the base; the outer molar margin bears a comb of curved bristles (Fig. 7).

Legs pale, femur with gray band along inner edge (Figs 1,2). Setation of outer femur margin includes acute bristles, longer than on the femur surface (Figs 11, 12), the longest bristles reach $27 \%$ of the femur width on foreleg (Fig. 11).

Pronotum brownish, rectangular, $1.4 \mathrm{x}$ wider than long, with rounded corners; a thin, transverse, anteromesal, pale band occupies $1 / 7$ of the pronotum length (in female larva); an X-shaped pattern of small dark brown rugosities is bounded by a semicircular line anteriorly (Figs 1,2). Setal pronotal fringe of acute bristles slightly irregular, longer at anterior and posterior margins, and especially conspicuous along medial pronotal line, where the longest acute bristles are $11.4 \%$ of pronotal width (Figs 9, 10). Scutum of meso- and metanotum are brown with diffuse $v$-shaped anterior pale patch (Fig. 2). Males without wing pads; in female hind wingpads are shallowly notched approximately halfway along inner margins (Fig. 2).

Abdominal terga 1-8 brown, pale integument, matte in appearance; terga 9-10 paler; terga 2-10 with three pairs of dark brown spots: the first pair is the largest, located laterally; the second pair appears anteromesally; the third pair is between the first and second pairs (Fig. 2). Terga have significantly heterogeneous chaetotaxy (Fig. 20), covered with dense relatively long acute bristles and sparse thin hairs. Some acute bristles are raised and clearly noticeable: length is $<22 \%$ of segment length (Fig. 13). The posterior margins on terga 57 feature acute bristles of different length, with at least one pair of conspicuous, relatively long, slightly curved hair-like bristles submedially: length up to half a segment length (Fig. 13).

Evident sexual dimorphism: females without posterior extension of tergum 10; males have elongated tergum 10 , truncated posterior margin, nearly straight dorsally with weak median notch (Figs 1, 2). Paraprocts rounded (Fig. 14).

Cerci pale, with $>18$ cylindrical segments; basal segments (Figs 15-16) short but gradually elongated toward the apex where they are very slender. The width of apical cercal segments is $1 / 8$ of their length (Figs 19, 20). Cercal segments have an apical whorl of short and relatively long acute bristles and few thin intercalary hairs, hairs are sparse and poorly developed, a few of which are on mesal and apical cercal 


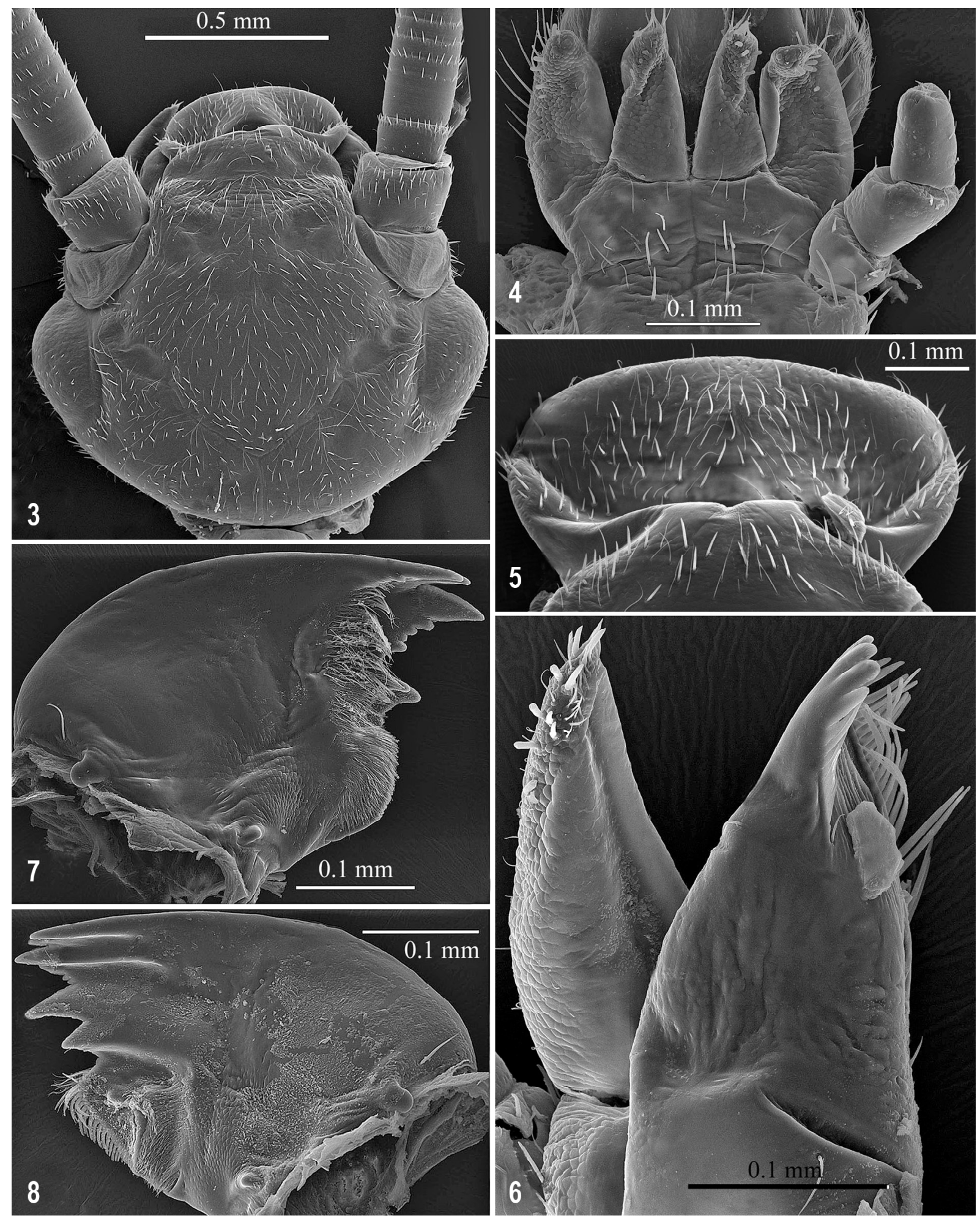

Figs 3-8. Capnia arensi Zhiltzova, larvae. 3 - head, dorsal; 4 - labium, glossa, paraglossa, and labial palp, ventral; 5 - labrum, dorsal; 6 - left lacinia and galea, ventrolateral; 7 - left mandible, ventral; 8 - right mandible, ventral.

Pис. 3-8. Capnia arensi Zhiltzova, мичинка. 3 - голова, виА сверху; 4 - нижняя губа, глосса, параглосса и нижнечелюстной шупик, виА снизу; 5 - верхняя губа, сверху; 6 - мевая мациния и галея, виА снизу и сбоку; 7 - левая мандибула, снизу; 8 - правая мандибула, снизу. 

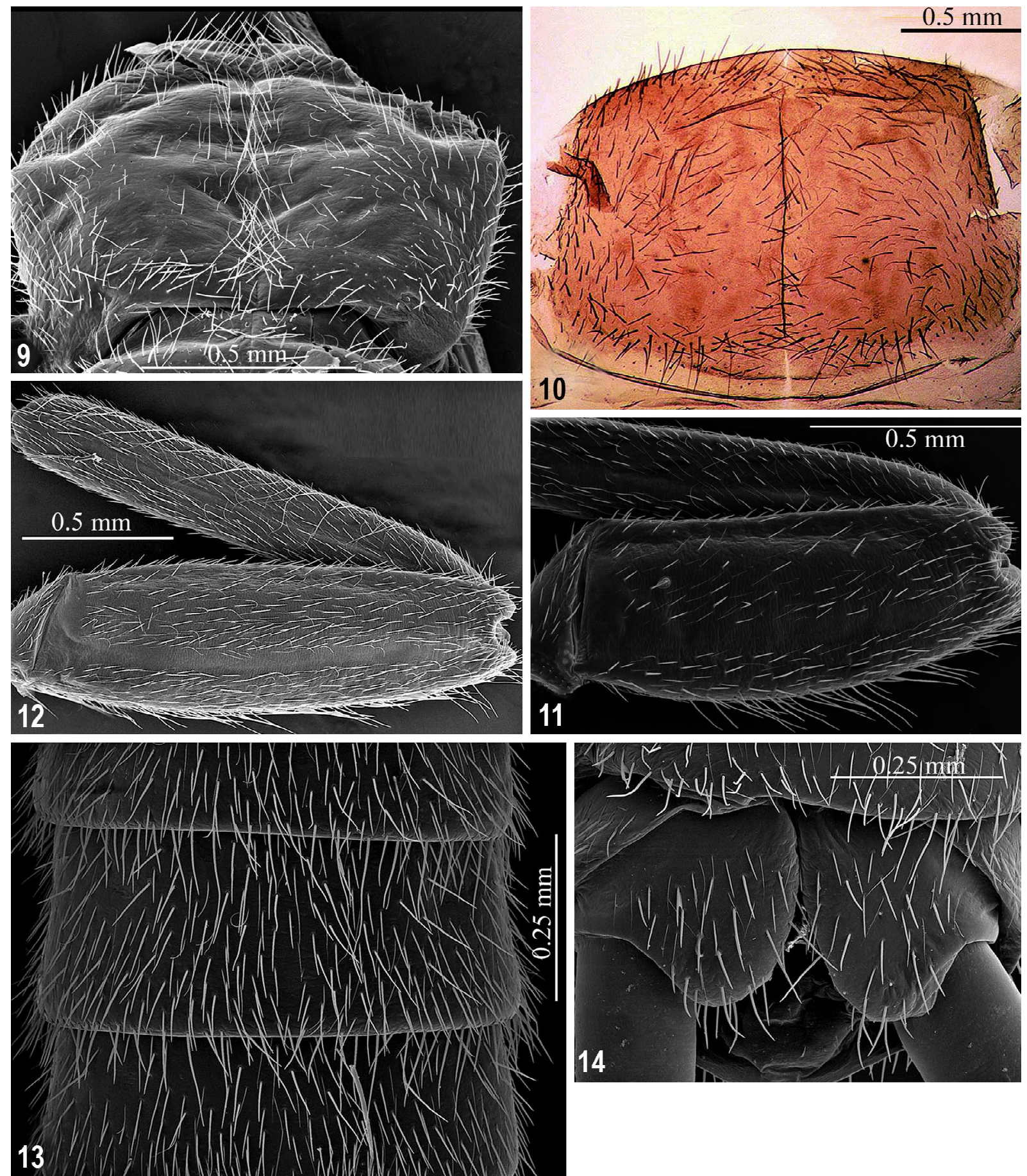

Figs 9-14. Capnia arensi Zhiltzova, larvae. 9-10 pronotum, chaetotaxy, dorsal; 11 - right foreleg, dorsal; 12 - right hind leg, dorsal; 13 - abdominal terga 5-7, dorsal; 14 - paraprocts, ventral.

Pис. 9-14. Capnia arensi Zhiltzova, мичинка. 9-10 переднеспинка, опушение, виА сверху; 11 - правая передняя нога, сверху; 12 - правая задняя нога, сверху; 13 - тергиты брюшка 5-7, сверху; 14 - парапрокты, снизу.

segments (Figs 17-20). Apical whorl includes one relatively long dorsal bristle on the basal segments, and long dorsal and ventral bristles on the mesal and apical cercal segments (Figs 16-19). Dorsal bristles are slightly longer than the ventral ones; length of the longest dorsal bristles can reach half the segment length of basal and mesal cercal segments (Figs 16-18).
Diagnosis. The larvae of $C$. arensi distinguish in heterogeneous setation of acute bristles and thin hairs on the pronotum, legs, abdominal and cercal segments. Setal pronotal fringe of acute bristles slightly irregular, longer at anterior and posterior margins, especially conspicuous along medial pronotal line, where the longest acute bristles amount $11.4 \%$ of pronotal width. Setation of outer femur margin includes acute 


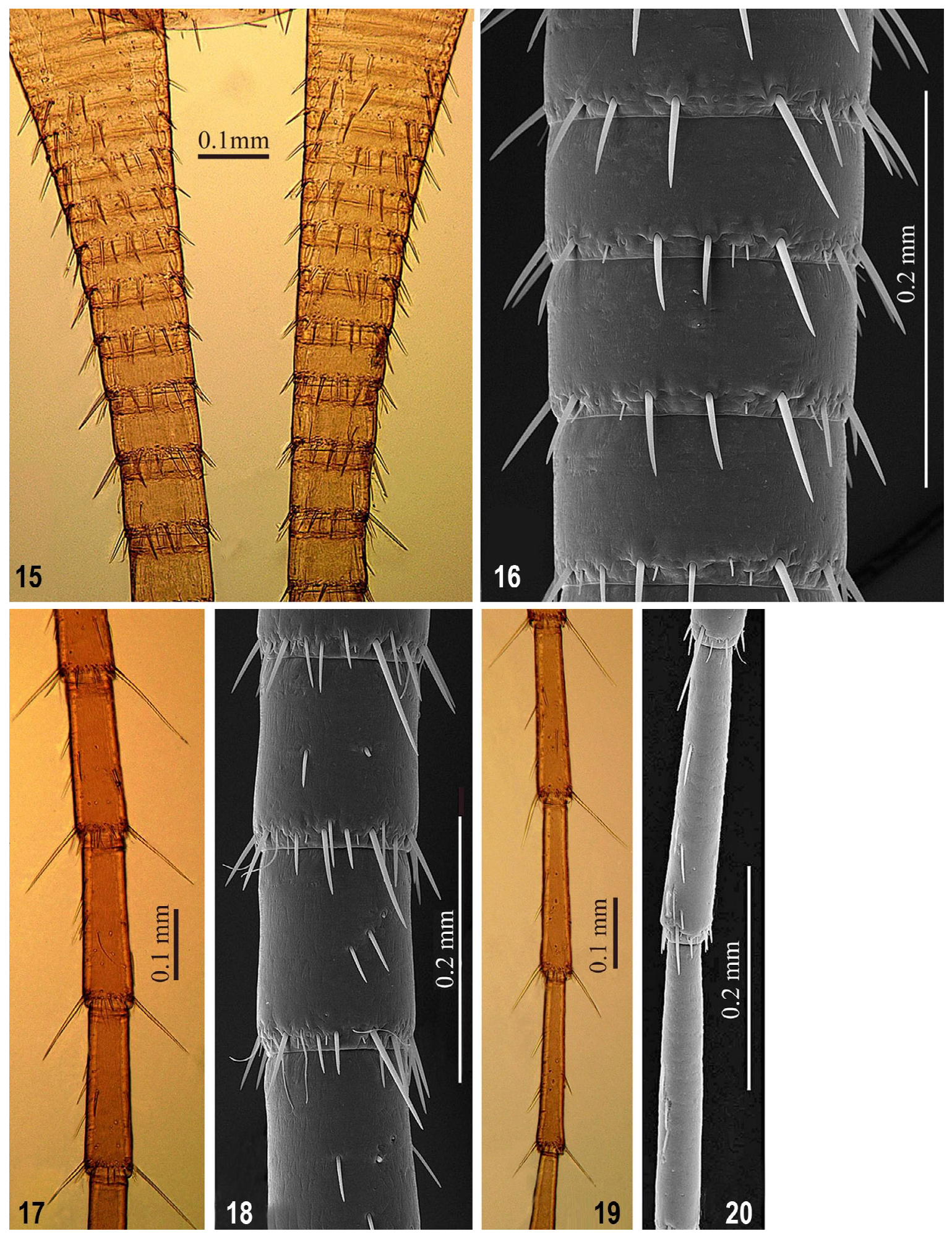

Figs 15-20. Capnia arensi Zhiltzova, larvae, cerci, dorsal. 15 - cerci, basal segments; 16 - right cercus, basal segments with stout acute bristles; 17-18 - middle segments with stout acute bristles, sparse hairs and intercalary setae; $19-20-$ apical segments, with sparse intercalary setae.

Рис. 15-20. Capnia arensi Zhiltzova, мичинка, церки, вид сверху. 15 - церки, базальные сегменты; 16 - правая церка, базальные сегменты с крепкими острыми щетинками; 17-18 - среАние сегменты с крепкими острыми шетинками, реАкими волосками и интеркалярными щетинками; 19-20 - апикальные сегменты с редкими интеркалярными щетинками. 
bristles, longer than on the femur surface, the longest bristles reach $27 \%$ of the femur width on foreleg. Abdominal terga cover with dense long acute bristles and sparse thin hairs; a few long acute bristles raised, length does not exceed $22 \%$ of segment length; the posterior margins bears bristles of different length; at least one pair of conspicuous, hair-like bristles, length up to half a segment length on terga 5-7. The apical circlet in mesal and apical cercal segments differ from the apical whorl on basal segments having longer dorsal and ventral bristle. Dorsal bristle is slightly longer than the ventral one; length of the longest dorsal bristle can reach half the segment length on basal and mesal cercal segments. Intercalary hairs on basal cercal segments absent, in mesal and apical cercal segments intercalary hairs are short, sparse and poorly developed.

Distribution and ecology. C. arensis belongs to the pedestris group that has a mainly central Asian distribution [Zwick, Sivec, 1980]. This species inhabits Eurasia also the watercourses of the mountain system of the Greater Caucasus: Russia (Karachay-Cherkessiya, North Ossetia); Georgiya; Armeniya, and Turkey (Pontic Mountains, Anatoliya) [Zhiltzova, 1964; Zwick, 1975; Kazanci, 1982; Vinçon, Sivec, 2011; Darilmaz et al., 2016]. An orophilic, stenothermal cold water species occurring in fast flowing and relatively large mountain streams, at altitude 1000 $2600 \mathrm{~m}$ above sea level. Adults emerge in winter and spring (December-June) and are often captured on snow. The collection was carried out in the clear-weather dark evening, from $8 \mathrm{pm}$. to $11 \mathrm{pm}$. Adults, including copulating individuals, were collected from snow-covered stones in the floodplain and along the river, at a distance of no more than $30 \mathrm{~m}$ from it, at temperatures of $-5--7^{\circ} \mathrm{C}$. The maximal abun-

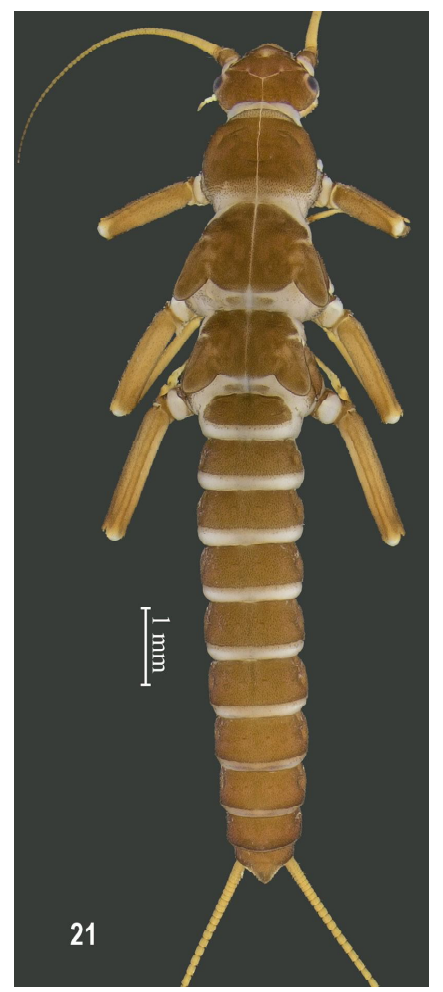

Figs 21. Capnia (Capnia) longicauda Zhiltzova, larvae, female, habitus.

Pис. 21. Capnia (Capnia) longicauda Zhiltzova, мичинка самки, общий виА. dance of adults occurred around the moon glares on the snow. Mature larvae, which were ready to emerge, were also sampled in the evening using a flashlight from rocky shallow waters at a current velocity of $0.2-0.3 \mathrm{~m} / \mathrm{s}$ (Figs 40-41). C. arensi was collected with Leuctra fusca (Linnaeus, 1758) females and larvae of Protonemura sp.

\section{Capnia (Capnia) longicauda Zhiltzova, 1969} Figs $21-39$

Zhiltzova, 1969: 596, figs 1-4; Zwick, 1973: 374; Zwick, Sivec, 1980: 72, figs 7a, d; Zhiltzova, 2003: 360, figs 603-605; Teslenko, Zhiltzova, 2009: 203, figs 124-1126; Muranyi, Li, Yang, 2015: 379; Yang, Li, Zhu, 2015: 449; Chandra, Gupta, Ahmed, 2019: 208; Teslenko, Palatov, 2021: 127, figs 11-12.

Material. China, Eastern Tien Shan, the Xinjiang Uygur Autonomous Region: Bogdo-Ula Range, Urumqi city, Dabancheng District, Lake Sangecha, altitude 3,503 m a.s.l., 12.VII.2017, $43^{\circ} 48.228^{\prime} \mathrm{N}, 88^{\circ} 16.339^{\prime}$ E, coll. D. Palatov, $90^{\prime} 0^{7}$, 19, 10 larvae, 3 exuviae.

Description. Mature larvae. Body prolonged, general color is brown without pattern (Fig. 21), body length 9.2$14.3 \mathrm{~mm}$ in females, $6,5 \mathrm{~mm}$ in male. Head bears a small diffuse pale spot in front of the anterior ocellus; epicranial suture thin and pale, a paired small pale patches bordering suture near lateral edges of head; M-line, tentorial callosities, and brown occipital rugosities on occiput inconspicuous (Fig. 21). Glossa and paraglossa subequal in length, both triangular with wide base, outer margins rounded; labial palp short, with longest third segment (Fig. 23). Labrum trapezoid narrowed posteriorly, anterior corners almost straight (Fig. 24). Galea fringed apically with a comb of bristles, hairs, and a few sensilla, small and short bristles present on outer margin, inner margin glabrous (Fig. 25). Lacinia is triangular and palmate with longitudinally striate surface and four relatively broad apical teeth (Fig. 25). Dorsal comb of 20 strong bristles, and ventral comb of 10 bristles, shorter than dorsal comb (Fig. 25). Right mandible basally wide, with a rounded outer margin and six pointed apical teeth: two teeth larger than the rest, the first and fourth teeth serrated basally (Fig. 27). Below the first apical teeth, a dense thin hairs form an arcuate curved inner row directed toward the molar pad; numerous dense hairs along outer molar margin. Left mandible has six pointed apical teeth also: forth apical tooth serrated at the base; the outer molar margin bears about 20 moderately long bristles (Fig. 26). Pale antenna long, includes $>73$ segments (Fig. 21). edge.

Legs pale brownish, femur with brown band along inner

Pronotum brown, without pattern, ovate-orbicular, 2,1x wider than long, a paired semicircular folds appeared parallel to anterior angles, and one wide, $\mathrm{v}$-shaped mesal fold in the last $1 / 3$ of pronotal length (Figs. 21, 28). Meso- and metanotum brown, with diffuse dark brown patches.

Abdominal terga brown, pale integument, matte in appearance (Fig. 21). Tergum 10 prolonged and rounded posteriorly in females (Fig. 21); in male the posterior margin of tergum 10 triangular. Paraprocts have short rectangular tips (Fig. 33). Pale long cerci with $>46$ cylindrical segments; basal segments short but gradually elongated toward the apex where they are slender, the width of apical segments is $1 / 5$ of their length (Figs 38-39).

Homogenous setation barely noticeable, includes uniform acute thin bristles of different lengths, is more pronounced in the head and abdominal terga. Setation of the head and pronotum bear short acute bristles, excepting for the suture and rugosities devoid of chaetotaxy; compound eyes covered with tiny setae (Figs 21, 22, 28, 29). Glossa with a few acute bristles, thin hairs, and papillae apically; paraglossa enclosed 

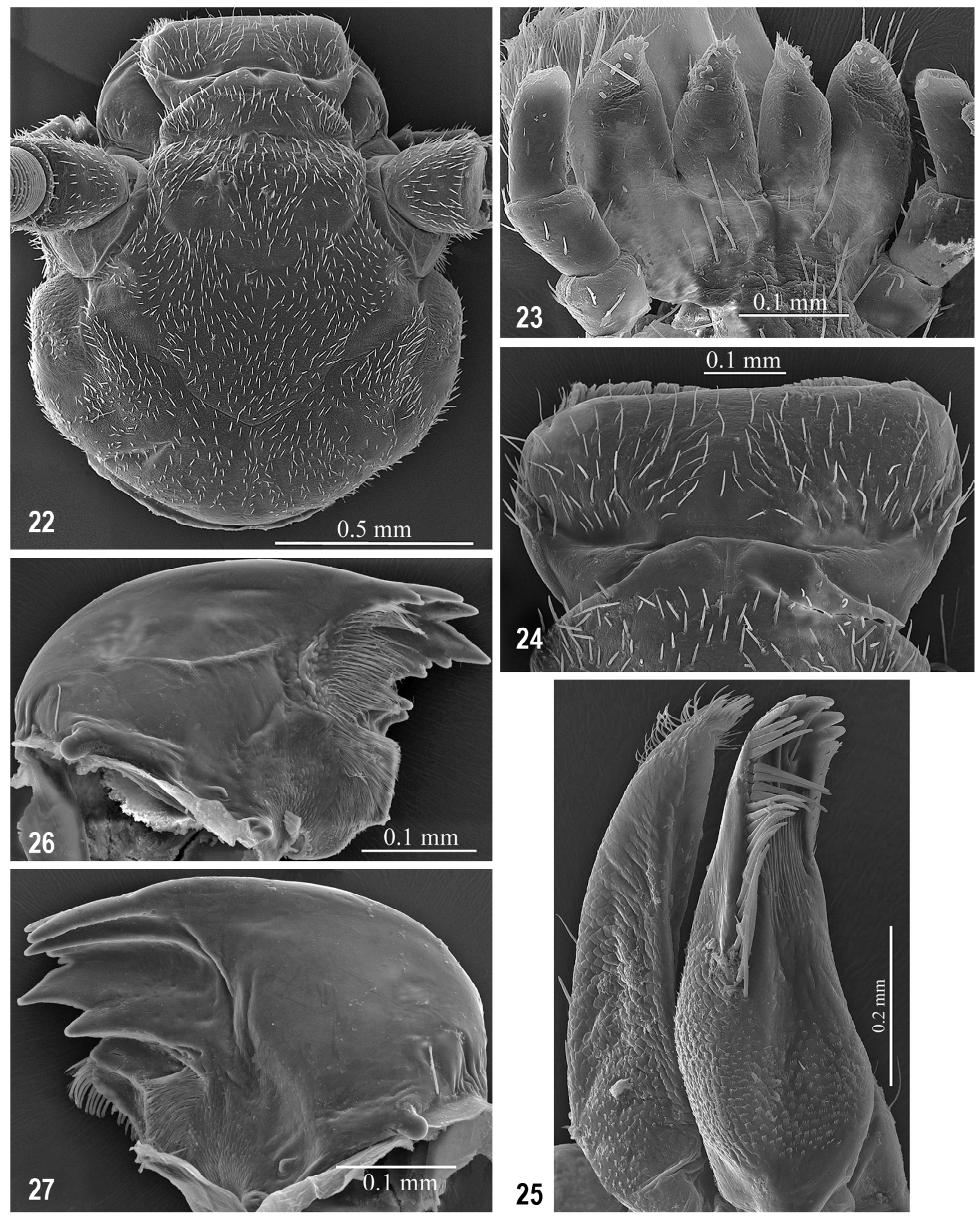

25

Figs 22-27. Capnia (Capnia) longicauda Zhiltzova, larvae. 22 - head, dorsal; 23 - labium, glossa and paraglossa, labial palp, ventral; 24 - labrum, dorsal; 25 - left lacinia and galea, ventrolateral; 26 - left mandible, ventral; 27 - right mandible, ventral.

Pис. 22-27. Capnia (Capnia) longicauda Zhiltzova, мичинка. 22 - голова, сверху; 23 - нижняя губа, глосса и параглосса, нижнечелюстной щупик, снизу; $24-$ верхняя губа, сверху; 25 - кевая кациния и галея, снизу и сбоку; 26 - кевая мандибула, снизу; 27 - правая мандибула, снизу. 

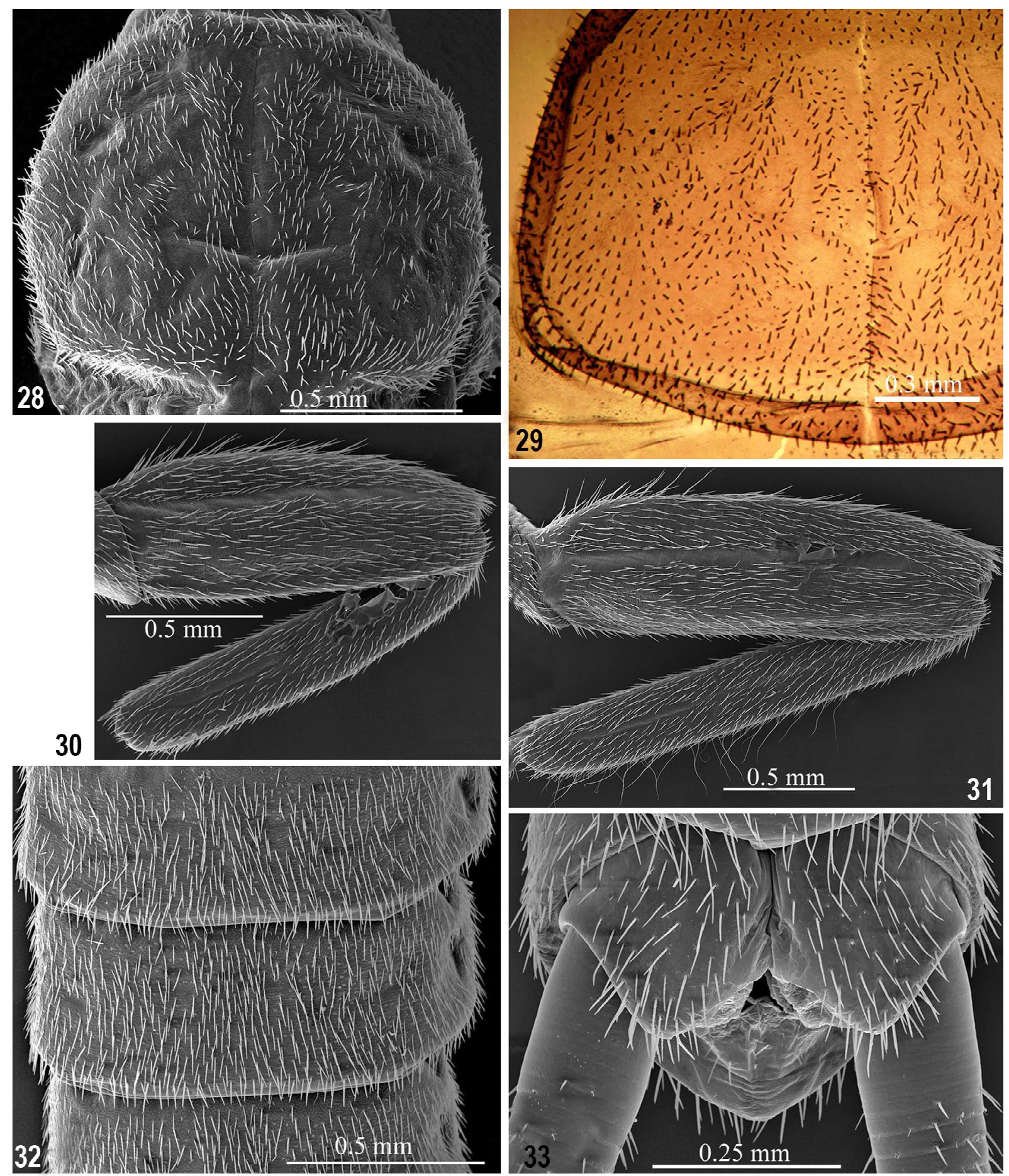

Figs 28-33. Capnia (Capnia) longicauda Zhiltzova, larvae. 28 - pronotum, chaetotaxy, dorsal; 29 - pronotum, left lateral and posterior margins, dorsal; 30 - left foreleg, dorsal; 31 - left hind leg, dorsal; 32 - abdominal terga 5-7, dorsal; 33 paraprocts, ventral.

Pис. 28-33. Capnia (Capnia) longicauda Zhiltzova, мичинка. 28 - опушение переднеспинки, сверху; 29 - мевый боковой и задний края переднеспинки, сверху; 30 - мевая передняя нога, сверху; 31 - кевая задняя нога, сверху; 32 - тегиты брюшка 5-7, сверху; 33 - парапрокты, снизу.

with similar setation (Fig. 23), with exception of the longest hairs like bristles covered paraglossa dorsally along outer edge (Fig. 23).

Setal fringe around the pronotum the same as on head, is relatively regular and dense, consisting of short acute bristles, length of the longest bristles at the posterior pronotal corners attains $4.0 \%$ of pronotal width (Figs 28, 29).

Femur and tibia feature the same acute bristles; setal fringe on the outer femur margin including few long acute bristles in regular arrangement, the longest bristles reach 

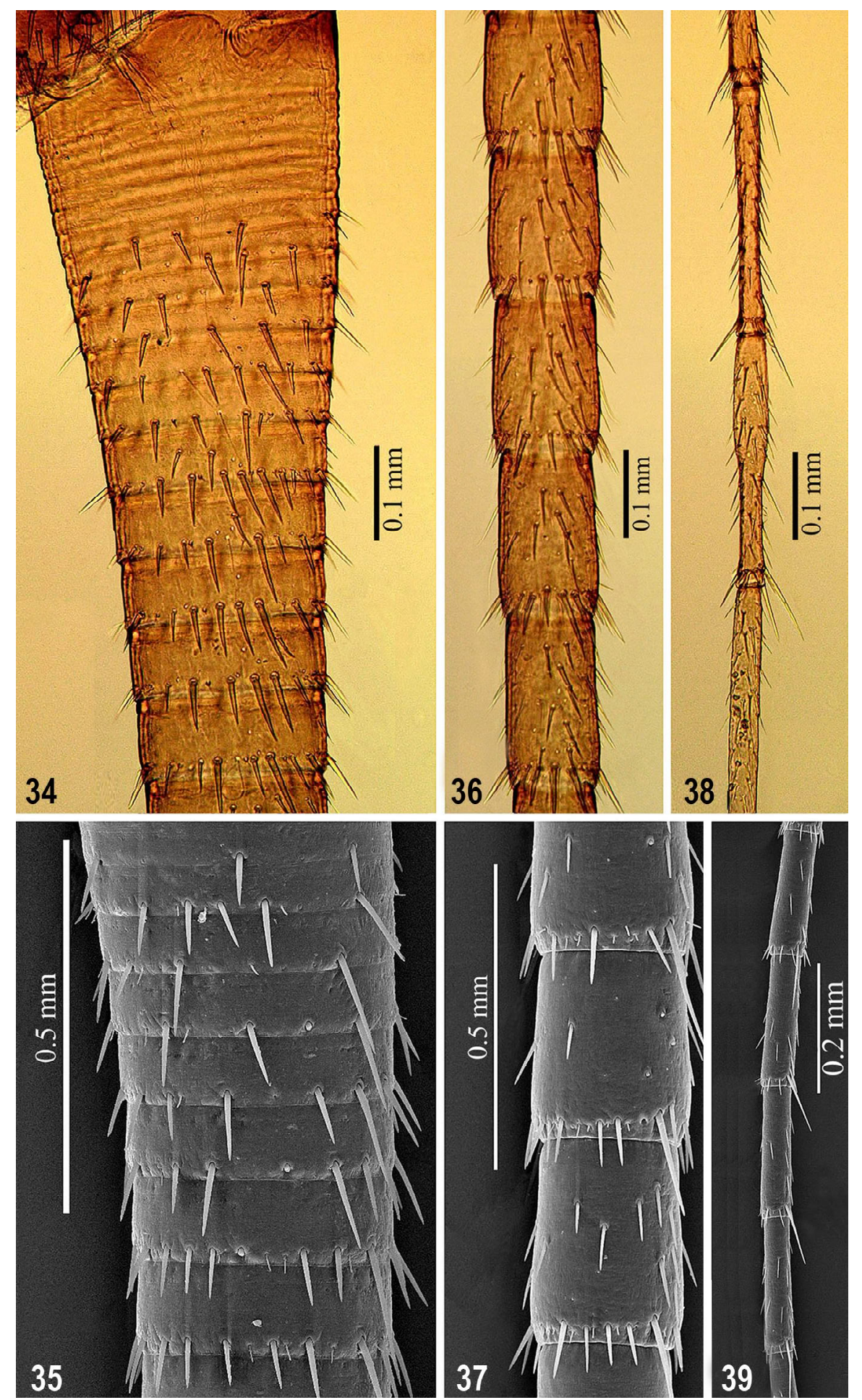

Figs 34-39. Capnia (Capnia) longicauda Zhiltzova, larvae, cerci, dorsal. 34-35 - right cercus, basal segments, dorsal; 3637 - middle cercal segments, dorsal; 38-39 - apical cercal segments, dorsal.

Рис. 34-39. Capnia (Capnia) longicauda Zhiltzova, кичинка, церки, сверху. 34-35 - правая церка, базальные сегменты, сверху; 36-37 - средние сегменты, сверху; 38-39 - апикальные сегменты, сверху.

$33 \%$ of femur width on the foreleg; sparse swimming hairs present on the outer tibia margin, more pronounced on hind leg (Figs 30, 31).

Abdominal terga 5-7 covered with dense acute bristles, posterior margins with the same acute bristles as on tergal surface, in regular arrangement (Fig. 32), their length does not exceed $15 \%$ of the tergal length.

Cerci with acute bristles and few tiny short thin hairs in the apical whorl, intercalary setation well developed in mesal and apical parts (Figs 36-39). Apical whorl of basal cercal 

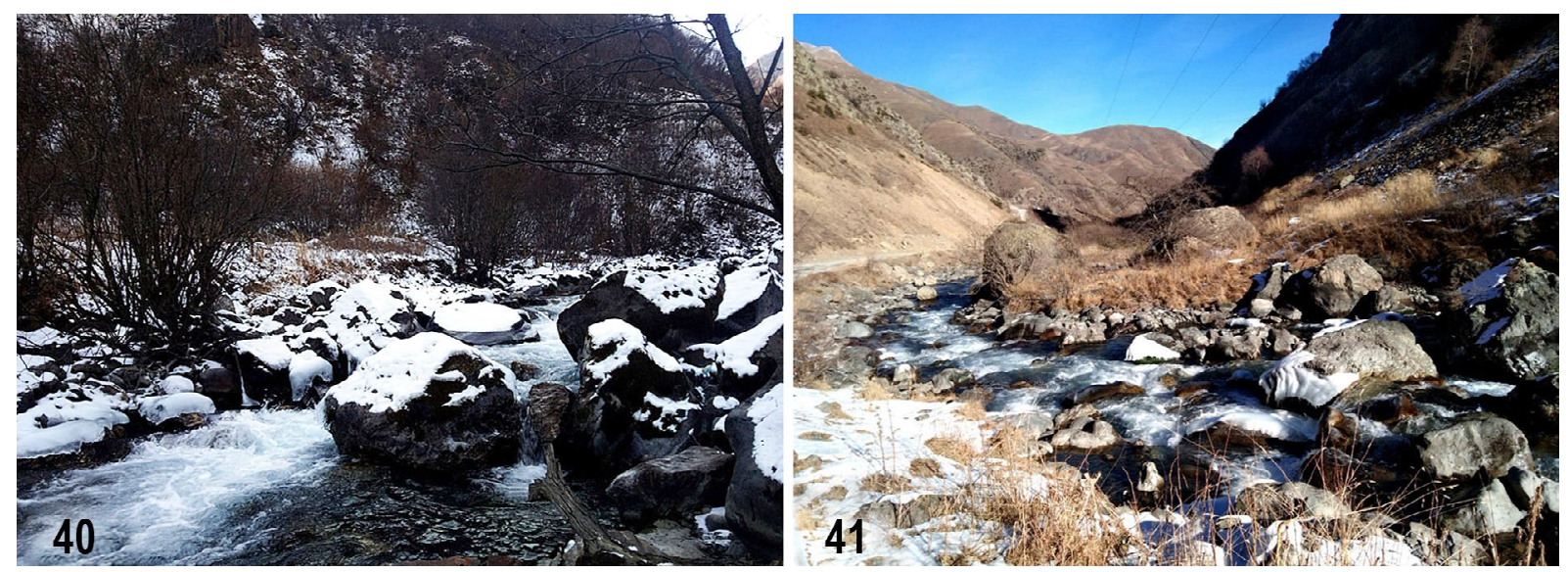

Figs 40-41. Habitats of Capnia arensi Zhiltzova, Fiagdon River, North Ossetia, the Greater Caucasus.

Рис. 40-41. Место обитания мичинок Capnia arensi Zhiltzova, p. Фиагдон, Северная Осетия, Кавказ.

segments with one acute dorsal bristle slightly longer than rest; the length of this bristle about $110 \%$ of segment's length on basal cercal segment 5-6 (Fig. 34, 35); in apical whorl of the mesal cercal segments the longest dorsal bristle not exceeding $56 \%$ of segment's length (Figs 36-37); setal ring of apical cercal segments bears sparse bristles, length of the longest dorsal bristle reducing to $47 \%$ of segment length, intercalary bristles are more evident on a light microscope slide (Figs 38-39).

Diagnosis. The larvae of Capnia (Capnia) longicauda are brown without conspicuous pattern. Antenna long includes 73 or more segments, cerci with 46 or more cylindrical segments. The larvae are distinguished by uniform acute bristles of the different lengths. Fringe on pronotal margins is regular and dense; the longest acute bristles reach $15.0 \%$ of pronotal width at the posterior corners. On the fore leg the outer femur margin bears prolonged acute bristles in regular arrangement; their length not exceeds $33 \%$ of femur width. The posterior tergal margins feature the same acute bristles as on tergal surface, bristles attaining $4.0 \%$ of the segment length on terga 5-6. Cerci have the intercalary hairs developed mainly in the mesal and apical parts. Apical whorl of cercal segments with one acute dorsal bristle slightly longer than rest; the length of this bristle decreased from $110 \%$ of segment's length on basal cercal segments to $47 \%$ of segment's length on apical cercal segments.

Distribution and ecology. Capnia (Capnia) longicauda has the widest distribution in the Palaearctic and Oriental Regions. The species was reported in Tian-Shan, the Eastern Himalayas, and Karakoram, including Kyrgyzstan, Eastern China, Nepal and Indiya [Zhiltzova, 1969, Zwick, Sivec, 1980; Muranyi et al., 2015; Chandra et al., 2019; Teslenko, Palatov, 2021]. Capnia (Capnia) longicauda occurs at altitudes of 2000-5150 m above sea level at the foot of glaciers and in glacial lakes, in the upper reaches of mountain streams and rivers. This species was collected in alpine glacial Sangecha Lake, the Bogdo-Ula Range at an altitude 3,503 m above sea level. Sangecha Lake is fed by a melting glacier and lies in a glacial cirque [Teslenko, Palatov, 2021, Figs 33, 34]. Even in July the Sangecha Lake is covered with ice. The emergence is extended from late May to late July.

\section{References}

Chandra K., Gupta D., Ahmed I. 2019. A Catalogue of Indian Stoneflies (Insecta: Plecoptera) // Zootaxa. Vol.4646. No.2. P. 201-235.
Darilmaz M.C., Salur A., Murányi D., Vinçon D. 2016. Contribution to the knowledge of Turkish stoneflies with annotated catalogue (Insecta: Plecoptera) // Zootaxa. Vol.4074. No.1. P.1-74.

DeWalt R. E., Maehr M. D., Hopkins H., Neu-Becker U., Stueber G. 2021. Plecoptera Species File Online. Version 5.0/5.0.

Illies I. 1966. Katalog der rezenten Plecoptera // Das Tierreich Eine Zusammenstellung und Kennzeichnung der rezenten Tierformen. Bd.82. S.1-631.

Kazanci N. 1982. Plecoptera (Insecta) species from Middle Anatolia // Entomologischen Mitteilungen der zoological Museum, Hamburg. Bd.7. P.195-201.

Linnaeus C. 1758. Neuroptera // Linnaeus C., Systema Naturae. 10th Edition. Impensis Direct. Laurentii Salvii, Holmiae. P. 543-552.

Murányi D., Gamboa M., Orci K.M. 2014. Zwicknia gen. n., a new genus for the Capnia bifrons species group, with descriptions of three new species based on morphology, drumming signals and molecular genetics, and a synopsis of the west Palaearctic and Nearctic genera of Capniidae (Plecoptera) // Zootaxa. Vol.3812. No.1. P.1-82.

Murányi D., Li W., Yang D. 2015. A new genus and species of winter stoneflies (Plecoptera: Capniidae) from Southwest China, with a commented checklist of the family in the Oriental Realm // Zootaxa. Vol.4059. No.2. P.371-382.

Pictet F.J. 1841. Histoire naturelle des insectes Névroptères. Famille des Perlides. Kessmann-Baillière. Genève-Paris. $423 \mathrm{p}$.

Stewart K.W., Stark B.P. 2002. Nymphs of North American stonefly genera (Plecoptera), Second Edition. Columbus: The Caddis Press. Ohio. 510 p.

Stewart K.W., Drake E.F., Stark B.P. 2011. Larvae of five species of the winter stonefly genus Capnia (Plecoptera: Capniidae) from California, U.S.A. // Illiesia. Vol.7. No.18. P.167-181.

Teslenko V.A., Palatov D.M. 2021. A poorly known species and new records of Plecoptera from the Eastern Tien Shan, Xinjiang Uygur Autonomous Region, China // Zootaxa. Vol.4950. No.1. P.123-136.

Teslenko V.A., Zhiltzova L.A. 2009. Keys to the stoneflies (Insecta, Plecoptera) of Russia and adjacent countries. Imagines and larvae. Vladivostok: Dalnauka. 382 p. [In Russian].

Vinçon G., Sivec I. 2011. Contribution to the knowledge of the Capniidae (Plecoptera) of Turkey // Illiesia. Vol.7. No.11. P.118-126.

Yang D., Li W.H., Zhu F. 2015. Fauna Sinica Insecta 58. Plecoptera: Nemouroidea. Beijing: Science Press. 518 p.

Yang D., Li W.H. 2018. Species catalogue of China. Vol.2 Animals, Insecta (III), Plecoptera. Beijing: Science Press. 71 p.

Zhiltzova L.A. 1964. To the knowledge of the stoneflies (Plecoptera) of Caucasus VI. New species of Taeniopterygidae, 
Nemouridae and Capniidae // Entomologicheskoe Obozrenie. Vol.43. No.2. P.347-362. [In Russian].

Zhiltzova L.A. 1969. New and rare species of stoneflies of fam. Capniidae (Plecoptera) from Central Asia // Entomological Review. Vol.48. No.3. P.593-611. [In Russian].

Zhiltzova L.A. 2003 Plecoptera. Grupper Euholognatha // Fauna of Russia and neighboring countries. New Series.145. Vol.1. Issue 1. St. Petersburg: Nauka. 538 p. [In Russian].
Zwick P. 1973. Insecta: Plecoptera. Phylogenetisches System und Katalog. Das Tierreich. Berlin: Walter de Gruyter. Bd.94. xxxii +465 p.

Zwick P. 1975. Weitere Plecoptera aus Anatolien // Mitteilungen der Schweizerischen entomologischen Gesellschaft. Bd.48. No.3/4. S.387-396.

Zwick P., Sivec I. 1980. Beitrage Zur Kenntnis der Plecoptera des Himalaya // Entomologica Basiliensia. Vol.5. P.59-138.

Поступила в редакцию 27.7.2021 